\title{
Comparative characterization of three bacterial exo-type alginate lyases
}

\author{
Makoto Hirayama $^{1}$, Wataru Hashimoto ${ }^{1}$, Kousaku Murata ${ }^{2}$, Shigeyuki Kawai ${ }^{1}$ * \\ ${ }^{1}$ Laboratory of Basic and Applied Molecular Biotechnology, Division of Food Science \\ and Biotechnology, Graduate School of Agriculture, Kyoto University, Uji, Kyoto \\ 611-0011, Japan
}

${ }^{2}$ Faculty of Science and Engineering, Department of Life Science, Setsunan University, Neyagawa, Osaka, Japan

* Corresponding author.

Tel. +8177438 3768; fax. +81774383767 .

E-mail address: kawais@kais.kyoto-u.ac.jp

Key words: alginate, exo-type alginate lyase, uronate 


\begin{abstract}
Alginate, a major acidic polysaccharide in brown macroalgae, has attracted attention as a carbon source for production of ethanol and other chemical compounds. Alginate is monomerized by exo-type alginate lyase into an unsaturated uronate; thus, this enzyme is critical for the saccharification and utilization of alginate. Although several exo-type alginate lyases have been characterized independently, their activities were not assayed under the same conditions or using the same unit definition, making it difficult to compare enzymatic properties or to select the most suitable enzyme for saccharification of alginate. In this study, we characterized the three bacterial exo-type alginate lyases under the same conditions: A1-IV of Sphingomonas sp. strain A1, Atu3025 of Agrobacterium tumefaciens, and Alg17c of Saccharophagus degradans. A1-IV had the highest specific activity as well as the highest productivity of uronate, whereas Alg17c had the lowest activity and productivity. Only dialyzed Atu3025 and Alg17c were tolerant to freezing. Alg17c exhibited a remarkable halotolerance, which may be advantageous for monomerization of alginate from marine brown algae. Thus, each enzyme exhibited particular desirable and undesirable properties. Our results should facilitate further utilization of the promising polysaccharide alginate.
\end{abstract}




\section{Introduction}

Alginate is a major acidic polysaccharide in brown macroalgae. For example, fronds of the brown algae Laminaria digita contain 25-44\% alginate (by dry weight); stipes of L. digita, 35-47\%; fronds of Laminaria hyperborea, 17-33\%; stipes of $L$. hyperborea, 25-38\%; and genus Sargassum, 3.3-41\% [1, 2]. Alginate consists of $\beta$-D-mannuronate (M) and its C5 epimer $\alpha$-L-guluronate $(\mathrm{G})$, arranged as polyM, polyG, and heteropolymeric random sequences (polyMG) [3]. Recently, alginate has attracted attention as a carbon source for production of ethanol and other chemical compounds, largely because of the advantages of brown macroalgae over land crops: higher productivity; no requirement for arable land, irrigation water, or fertilizer; and the absence of lignin [4-7]. Takeda et al. initially succeeded in producing ethanol from alginate using a bioengineered bacterium, Sphingomonas sp. strain A1 [8]. Subsequently, ethanol production from alginate and mannitol, another major carbohydrate in brown macroalgae, was achieved using bioengineered Escherichia coli $[9,10]$. We also established a system for producing pyruvate from alginate using Sphingomonas sp. strain A1 [11].

In Sphingomonas sp. strain A1, alginate is depolymerized by endo-type alginate lyases (A1-I, A1-II, and A1-III) to produce oligoalginates [12], which are then degraded by exo-type alginate lyase (A1-IV) into an unsaturated uronate that is further non-enzymatically converted to 4-deoxy-L-erythro-5-hexoseulose uronate (DEH) [13, 14]. $\mathrm{DEH}$ is reduced to 2-keto-3-deoxy-D-gluconate (KDG) and metabolized to pyruvate $[15,16]$ (Fig. 1). Alginate is also directly monomerized to DEH by the exo-type alginate lyase. Thus, exo-type alginate lyase is a key enzyme for the saccharification and utilization of alginate. Moreover, Enquist-Newman et al. recently 
created a bioengineered yeast Saccharomyces cerevisiae that can produce ethanol from both mannitol and DEH [17], highlighting the significance of the exo-type alginate lyase that produces $\mathrm{DEH}$; industrial use of the exo-type alginate lyase enables us to prepare an industrial scale of DEH from alginate.

Several bacterial exo-type alginate lyases have been well characterized, including A1-IV of Sphingomonas sp. strain A1 (an alginate-assimilating bacterium) [13, 14], Atu3025 of Agrobacterium tumefaciens (the causal bacterium of crown gall) [18, 19], Alg17c of Saccharophagus degradans (a marine carbohydrate-degrading bacterium) [20-23], OalA, OalB, and OalC of Vibrio splendidus (a marine bacterium) [24], and AlyA5 of Zobellia galactanivorans (a marine bacterium) [25]. A1-IV, Atu3025, and OalA are classified as PL-15, AlyA5 is PL-7, whereas Alg17c, OalB, and OalC are PL-17. A1-IV was the first of these enzymes to be identified [13]. The tertiary structures of Atu3025 and Alg17c have been solved [21, 26], enabling the functions of these enzymes to be improved based on their structural information. Recently, Alg7K of S. degradans, belonging to PL7 [27], has been successfully expressed on the cell surface of $S$. cerevisiae and demonstrated to show the exo-type alginate lyase activity [28].

Although several exo-type alginate lyases have been characterized independently, their activities have not been assayed under the same conditions or using the same unit definition, making it difficult to compare their enzymatic properties or to select the most suitable enzyme for saccharification of alginate (Table 1). Therefore, we decided to characterize three bacterial exo-type alginate lyases, A1-IV, Atu3025, and Alg17c, under the same conditions in order to compare their activities. These 3 lyases 
were selected, since A1-IV is the first exo-type alginate lyase identified [13] and the tertiary structures of Atu3025 and Alg17c have been solved [21, 26].

\section{Materials and methods}

\subsection{Materials}

Sodium alginate (viscosity 1,000 cps, from Eisenia bicyclis) was purchased from Nacalai Tesque (Kyoto, Japan). DEH was prepared as described [16].

\subsection{Plasmid construction}

Primers and plasmids used in this study are listed in Tables 2 and 3, respectively. The genes encoding Alg17c, Atu3025, and A1-IV were amplified by PCR using KOD-Plus Neo (Toyobo, Osaka, Japan) in the presence of $8 \% \mathrm{v} / \mathrm{v}$ DMSO and 3.0 $\mathrm{mM} \mathrm{MgSO} 4$. Templates, primers, and annealing temperatures for amplification of the genes for Atu3025, Alg17c, and A1-IV were as follows. Atu3025: pMK4544, primers 1

and $2,54^{\circ} \mathrm{C}$; Alg17c: pMK5306, primers 3 and $4,52^{\circ} \mathrm{C}$; A1-IV: genomic DNA of Sphingomonas sp. strain A1 [29], primers 5 and $6,53^{\circ} \mathrm{C}$. The three amplified genes were inserted into pET-21b digested with NdeI and NotI using In-Fusion (Takara, Otsu, Japan), yielding pMK5400 (Atu3025), pMK5399 (Alg17c), and pMK5398 (A1-IV).

\subsection{Expression and purification of Alg17c, Atu3025, and A1-IV}

pMK5400 and pMK5398 were introduced into E. coli HMS174(DE3), yielding strains MK5407 and MK5405. pMK5399 was into E. coli BL21(DE3), yielding strain MK5406. Alg17c, Atu3025, and A1-IV were expressed in MK5406, MK5407, and MK5405 as described [14, 18, 20] with slight modifications: expression 
was induced by addition of $0.1 \mathrm{mM}$ isopropyl $\beta$-D-1-thiogalactopyranoside, and the cells were cultivated for $20-24 \mathrm{~h}$ at $16^{\circ} \mathrm{C}(\mathrm{Alg} 17 \mathrm{c}$ in $\mathrm{MK} 5406)$ or at $30^{\circ} \mathrm{C}$ (Atu3025 in MK5407 and A1-IV in MK5405). Alg17c, Atu3025, and A1-IV were expressed as C-terminally His-tagged fusion proteins. The expressed Alg17c lacks a 22 amino-acid N-terminal sequence $\left({ }^{2}\right.$ LSVNTIKNTLLAAVLVSVPATA $\left.{ }^{23}\right)[20]$.

Cells were disrupted by sonication, and expressed proteins were purified on a TALON Metal Affinity Resin column (Clontech, Otsu, Japan). The column was washed with $20 \mathrm{mM}$ Tris- $\mathrm{HCl}(\mathrm{pH}$ 7.5) plus $300 \mathrm{mM} \mathrm{NaCl}$, followed by elution with $20 \mathrm{mM}$ Tris- $\mathrm{HCl}(\mathrm{pH} 7.5)$ plus $300 \mathrm{mM} \mathrm{NaCl}$ and $150 \mathrm{mM}$ neutralized imidazole, as described [30].

\subsection{Assays}

Concentrations of the purified proteins were determined using the molecular coefficient $(\varepsilon)$ at $A_{280}\left(\mathrm{M}^{-1} \mathrm{~cm}^{-1}\right)$ and calculated molecular masses as follows: $\varepsilon=$ 186,725 and 87,825.7 Da (A1-IV), $\varepsilon=184,985$ and 89,149.5 Da (Atu3025), and $\varepsilon=$ 114,600 and $80,682.6 \mathrm{Da}(\mathrm{Alg} 17 \mathrm{c})$, corresponding to $0.47,0.48$, and $0.70 \mathrm{mg} / \mathrm{ml}$, respectively, at $A_{280}=1.0$. Exo-type alginate lyase activity was assayed by monitoring the release of $\mathrm{DEH}$ in a reaction mixture $[100 \mu \mathrm{l}, 1.0 \mathrm{mg} / \mathrm{ml}$ sodium alginate, $50 \mathrm{mM}$ Tris- $\mathrm{HCl}(\mathrm{pH} 7.5)$, and purified enzymes (usually $1 \mu \mathrm{g}$ of purified A1-IV, Atu3025, or Alg17c)] at $30^{\circ} \mathrm{C}$. After incubation, usually for 5 and $10 \mathrm{~min}$, reaction mixtures were boiled for $5 \mathrm{~min}$, and the concentration of $\mathrm{DEH}$ in the mixture was determined by the TBA method [18, 31]. For quantitative analysis, authentic KDG (Sigma-Aldrich) was used as a standard, giving the molecular coefficient of DEH at $A_{548}\left(\varepsilon=58,000 \mathrm{M}^{-1} \mathrm{~cm}^{-1}\right)$ in which molecular mass of DEH is $176 \mathrm{Da}$. Linearity of the activity was confirmed 
with respect to two time points and two protein concentrations. One unit of enzymatic activity was defined as the amount of enzyme required to release $1.0 \mu \mathrm{mol}$ of DEH in 1 $\min$.

\section{Results}

\subsection{Purification and stability of recombinant three exo-type alginate lyases}

Recombinant Alg17c, Atu3025, and A1-IV were expressed in E. coli using the pET system and purified as C-terminal His-tagged fusion proteins on a TALON affinity column (Fig. 2). Concentrations were determined using each protein's molecular coefficient at $A_{280}$. To evaluate enzymatic activity, we monitored the release of DEH, as determined by the TBA method [18], using the molecular coefficient of DEH at $A 548$ ( $\varepsilon$ $\left.=58,000 \mathrm{M}^{-1} \mathrm{~cm}^{-1}\right)$. To further confirm this coefficient, we prepared DEH from 3.0, 6.0, and $10.0 \mathrm{mg} / \mathrm{ml}$ sodium alginate solutions by complete digestion with purified Atu3025. Concentrations of these DEH were determined 3.0, 6.0, and $10.0 \mathrm{mg} / \mathrm{ml}$, respectively, when the coefficient of $\varepsilon=58,000$ was applied (data not shown), confirming the correctness of the coefficient.

The specific activities of purified proteins (A1-IV, Atu3025, and Alg17c), were $13.5 \pm 1.4 \mathrm{U} / \mathrm{mg}, 2.5 \pm 0.6 \mathrm{U} / \mathrm{mg}$, and $2.3 \pm 0.5 \mathrm{U} / \mathrm{mg}$ (average \pm standard deviation $[\mathrm{SD}], \mathrm{n}=3$ ), respectively, demonstrating that A1-IV had the highest activity. Because the purified enzyme solutions contained salts and imidazole [20 $\mathrm{mM}$ Tris- $\mathrm{HCl}$ (pH 7.5), $300 \mathrm{mM} \mathrm{NaCl}$, and $150 \mathrm{mM}$ imidazole], dialysis was conducted against 20 $\mathrm{mM}$ Tris- $\mathrm{HCl}(\mathrm{pH} 7.5)$ overnight at $4{ }^{\circ} \mathrm{C}$. However, the activity of purified AI-IV was almost completely lost after dialysis $(0.3 \pm 0.3 \mathrm{U} / \mathrm{mg})$, although the presence of $\mathrm{NaCl}$ slightly alleviated this effect (Fig. 3A). Atu3025 remained almost fully active, and 
Alg17c retained about half of its activity, following dialysis (Fig. 3A). The activity of dialyzed Atu3025 gradually decreased during storage at $4^{\circ} \mathrm{C}$ (Fig. 3B, C). Dialyzed Atu3025 was fully tolerant to freezing and dialyzed Aig17C was partially tolerant to freezing (Fig. 3D). Based on these observations, we decided to use purified and dialyzed Atu3025 and Alg17c, and purified A1-IV that was not dialyzed, for subsequent assays. Atu3025 and Alg17c were usually used for assays immediately after dialysis, but Atu3025 was sometimes used after freezing because it tolerated this treatment well. A1-IV was used immediately after purification.

\subsection{Properties of the three exo-type alginate lyases}

In order to examine the effects of reaction periods on DEH productivity (i.e., the amount of released DEH), each exo-type alginate lyase was incubated with 1.0 $\mathrm{mg} / \mathrm{ml}$ alginate in the presence of $50 \mathrm{mM}$ Tris- $\mathrm{HCl}(\mathrm{pH} 7.5)$ for longer periods (Fig. 4A). The amount of released DEH was the lowest in the case of Alg17c, and higher in the case of Atu3025 and A1-IV, which produced $0.7 \mathrm{mg} / \mathrm{ml} \mathrm{DEH}$ after $3 \mathrm{~h}$ and 0.6 $\mathrm{mg} / \mathrm{ml} \mathrm{DEH}$ after $9 \mathrm{~h}$, respectively; A1-IV had the highest productivity. Next, each exo-type alginate lyase was incubated for $6 \mathrm{~h}$ as above, but with $1.0,3.0$, or $9.0 \mathrm{mg} / \mathrm{ml}$ alginate (Fig. 4B). Again, Alg17c had the lowest DEH productivity. The productivities of A1-IV and Atu3025 were higher, and AI-IV had the highest productivity in the presence of $9.0 \mathrm{mg} / \mathrm{ml}$ alginate.

Exo-type alginate lyase activity was assayed in the presence of varying concentrations of $\mathrm{NaCl}$ (Fig. 4C). Atu3025 was slightly (1.16-fold) activated in the presence of $25 \mathrm{mM} \mathrm{NaCl}$, but almost all of the activity ( $>84 \%$ ) was inhibited in the presence of $200-600 \mathrm{mM} \mathrm{NaCl}$. By contrast, the activity of A1-IV was inhibited by 
$\mathrm{NaCl}$, and no activation of $\mathrm{A} 1-\mathrm{IV}$ by low concentrations of $\mathrm{NaCl}$ was observed. $\mathrm{Alg} 17 \mathrm{c}$ was activated (1.62-fold) by $100 \mathrm{mM} \mathrm{NaCl}$, and was remarkably more halotolerant than Atu3025 and A1-IV under saline conditions (200-600 $\mathrm{mM} \mathrm{NaCl}$ ); half of the activity (47\%) of Alg17c was retained even in the presence of $600 \mathrm{mM} \mathrm{NaCl}$, whereas the activity of A1-IV was highest at $100 \mathrm{mM} \mathrm{NaCl}$.

\section{Discussion}

In this study, three exo-type alginate lyases, Alg17c, Atu3025, and A1-IV were purified as C-terminally His-tagged proteins and simultaneously assayed under the same conditions using the same unit definition. The results revealed that A1-IV had the highest specific activity and DEH productivity. Furthermore, each enzyme exhibited particular desirable and undesirable properties. The obtained data should facilitate further utilization of the promising macromolecule alginate.

A1-IV was originally purified from Sphingomonas sp. strain A1 by Hashimoto et al., and recombinant A1-IV without a His-Tag was purified by Miyake et al., but their activities were assayed under different conditions, by different methods, or using different unit definitions than those in this study (Table 1) [13, 14]. Therefore, this study is the first to demonstrate the high specific activity and DEH productivity of A1-IV. Atu3025 was originally purified from A. tumefaciens, and recombinant Atu3025 was purified without a His-Tag by Ochiai et al. [18]. Those authors assayed specific activity under the same conditions that we used in this study, except that they performed their assay in the presence of $0.5 \mathrm{mg} / \mathrm{ml}$ alginate and used a molecular coefficient for DEH of $\varepsilon=29,000 \mathrm{M}^{-1} \mathrm{~cm}^{-1}$ (Table 1), whereas we used $1.0 \mathrm{mg} / \mathrm{ml}$ alginate and $\varepsilon=$ $58,000 \mathrm{M}^{-1} \mathrm{~cm}^{-1}$. The activity as originally determined by Ochiai et al. using $\varepsilon=29,000$ 
$\mathrm{M}^{-1} \mathrm{~cm}^{-1}$ was $13.6 \mathrm{U} / \mathrm{mg}$ [18]; therefore, the specific activity of the original Atu3025 is calculated to be $6.8 \mathrm{U} / \mathrm{mg}$ when $\varepsilon=58,000 \mathrm{M}^{-1} \mathrm{~cm}^{-1}$ is used, still higher than our measured activity $(2.5 \mathrm{U} / \mathrm{mg})$. We attribute this low activity of the recombinant Atu3025 prepared in this study to the His-tag at the C-terminus. On the other hand, Alg17c has not been purified from $S$. degradans, but recombinant Alg17c was purified by Kim et al. as a C-terminally His-tagged protein [20]. The specific activity of Alg17c was not described, although $V_{\max }$ was calculated as $41.7 \mathrm{U} / \mathrm{mg}$ [20]. However, Alg17c exhibited remarkable halotolerance as discussed below. Jagtap et al. characterized three recombinant exo-type alginate lyases (OalA, OalB, and OalC) and determined the specific activities of purified OalA, OalB, and OalC to be 29, 20, and $21 \mathrm{U} / \mathrm{mg}$, respectively, although they did not purify OalA, OalB, and OalC directly from $V$. splendidus [24]. Jagtap et al. assayed the exo-type alginate lyase activity of OalA, OalB, and OalC by the TBA method, and seemed to use the molecular coefficient for DEH of $\varepsilon=29,000 \mathrm{M}^{-1} \mathrm{~cm}^{-1}$, although this was not clearly stated. When $\varepsilon=58,000 \mathrm{M}^{-1} \mathrm{~cm}^{-1}$ was used, the specific activities of purified OalA, OalB, and OalC were calculated as 14.5, 10 , and $10.5 \mathrm{U} / \mathrm{mg}$, respectively, comparable to that of A1-IV (13.5 U/mg) determined in this study.

Saccharification into DEH represents one feasible method for utilization of alginate, as demonstrated [17]. To achieve this, a suitable exo-type alginate lyase is required as an enzyme reagent. In this regard, A1-IV, Atu3025, and Alg17c are easy to express and purify, and are thus promising enzyme reagents for this application. By contrast, expression and purification of recombinant OalA, OalB, and OalC are difficult [24]. In order to improve the expression of soluble recombinant OalA, the protein was expressed as a maltose-binding-protein (MBP)-fusion protein and treated with factor Xa 
to remove MBP. Recombinant OalB and OalC, which were expressed as C-terminally His-tagged proteins, were refolded using the flash dilution method before purification due to low expressions of soluble OalB and OalC [24]. Although A1-IV had high DEH productivity (Fig. 4), it was sensitive to freezing (Fig. 3D), and therefore could not be stored in frozen form for long periods. Moreover, A1-IV was sensitive to dialysis (Fig. $3 \mathrm{~A})$, and it would therefore be hard to remove contaminating salts from preparations of this protein. In contrast to A1-IV, Atu3025 and Alg17c were tolerant to dialysis (Fig. 3A). Moreover, dialyzed Atu3025 and Alg17c were tolerant to freezing (Fig. 3D) and could therefore be stored for longer periods. Atu3025 had higher specific activity and DEH productivity than Alg17c (Fig. 4). Therefore, Atu3025 is the most suitable enzyme reagent for preparation of DEH. Structure-based improvement of the catalytic capacity of Atu3025 is feasible because the tertiary structure of Atu3025 is available [26].

The halotolerance of exo-type and endo-type alginate lyases has not been previously reported. In this study, we revealed that $\mathrm{Alg} 17 \mathrm{c}$ is halotolerant. Alg17c is derived from the marine bacterium $S$. degradans, which was isolated from salt marsh grass, Spartina alterniflora, found in the lower Chesapeake Bay [23, 32]. Although the localization of $A \lg 17 \mathrm{c}$ in $S$. degradans has not been reported, the localization prediction program PSORT [33] predicts the presence of N-terminal signal sequence, as reported [20], indicating that Alg17c is an outer membrane or periplasmic protein. Therefore, based on its probable localization, it is reasonable that Alg17c is halotolerant. This feature is pertinent to the utilization of brown macroalgae as a carbon source especially in the industrial hydrolysis condition, because algal materials are likely to contain salts and halotolerance is obviously the preferred property of the industrial enzyme. Thus, the halotolerance of Alg17c might be advantageous for the utilization of salty alginate. 


\section{Acknowledgments}

This work was supported by the 11th JSBBA Innovative Research Program Award (to S.K.), the 41th Iwatani Naoji Foundation Iwatani Scientific Technology, Research Grant-in-Aid (to S.K.), JST A-STEP FS-stage (AS262Z00582N) (to S.K.), Shorai Foundation For Science And Technology, Research Grant-in-Aid in 2015 (to S.K.), and Asahi Group foundation, Research Grant-in-Aid in 2015 (to S.K.). 


\section{References}

[1] M. Zubia, C. Payri, E. Deslandes, J. Appl. Phycol. 20 (2008) 1033-1043.

[2] M. Rinaudo, Seaweed polysaccharides, in: J.P. Kamerling, G.-J. Boons, Y.C. Lee, A. Suzuki, N. Taniguchi, A.G.J. Voragen (Eds.) Comprehensive glycoscience. From chemistry to system biology., Elsevier, Oxford, 2007, pp. 691-735.

[3] P. Gacesa, Carbohydr. Polym. 8 (1988) 161-182.

[4] M. Huesemann, G. Roesjadi, J. Benemann, F.B. Metting, Biofuels from microalgae and seaweeds, in: A. Vertès, N. Qureshi, H. Yukawa, H.P. Blaschek (Eds.) Biomass to biofuels: strategies for global industries, Wiley, 2010, pp. $165-184$.

[5] J.M. Adams, J.A. Gallagher, I.S. Donnison, J. Appl. Phycol. 21 (2009) 569-574.

[6] J.J. Yoon, Y.J. Kim, S.H. Kim, H.J. Ryu, J.Y. Choi, G.S. Kim, M.K. Shin, Adv. Mat. Res. 93-94 (2010) 463-466.

[7] R.P. John, G.S. Anisha, K.M. Nampoothiri, A. Pandey, Bioresour. Technol. 102 (2011) 186-193.

[8] H. Takeda, F. Yoneyama, S. Kawai, W. Hashimoto, K. Murata, Energy. Environ. Sci. 4 (2011) 2575-2581

[9] A.J. Wargacki, E. Leonard, M. N. Win, D. D. Regitsky, C. N. S. Santos, P. B. Kim, S. R. Cooper, R. M. Raisner, A. Herman, A. B. Sivitz, A. Lakshmanaswamy, Y. Kashiyama, D. Baker, Y. Yoshikuni, Science 335 (2012) $308-313$

[10] C.N. Santos, D.D. Regitsky, Y. Yoshikuni, Nat. Commun. 4 (2013) 2503. 
[11] S. Kawai, K. Ohashi, S. Yoshida, M. Fujii, S. Mikami, N. Sato, K. Murata, J. Biosci. Bioeng. 117 (2014) 269-274.

[12] H.J. Yoon, W. Hashimoto, O. Miyake, M. Okamoto, B. Mikami, K. Murata, Protein. Express. Purif. 19 (2000) 84-90.

[13] W. Hashimoto, O. Miyake, K. Momma, S. Kawai, K. Murata, J. Bacteriol. 182 (2000) 4572-4577.

[14] O. Miyake, W. Hashimoto, K. Murata, Protein Expr. Purif. 29 (2003) 33-41.

[15] K. Murata, S. Kawai, B. Mikami, W. Hashimoto, Biosci. Biotechnol. Biochem. 72 (2008) 265-277.

[16] R. Takase, A. Ochiai, B. Mikami, W. Hashimoto, K. Murata, Biochim. Biophys. Acta 1804 (2010) 1925-1936.

[17] M. Enquist-Newman, A.M. Faust, D.D. Bravo, C.N. Santos, R.M. Raisner, A. Hanel, P. Sarvabhowman, C. Le, D.D. Regitsky, S.R. Cooper, L. Peereboom, A. Clark, Y. Martinez, J. Goldsmith, M.Y. Cho, P.D. Donohoue, L. Luo, B. Lamberson, P. Tamrakar, E.J. Kim, J.L. Villari, A. Gill, S.A. Tripathi, P. Karamchedu, C.J. Paredes, V. Rajgarhia, H.K. Kotlar, R.B. Bailey, D.J. Miller, N.L. Ohler, C. Swimmer, Y. Yoshikuni, Nature 505 (2014) 239-243.

[18] A. Ochiai, W. Hashimoto, K. Murata, Res. Microbiol. 157 (2006) 642-649.

[19] C.I. Kado, Front. Microbiol. 5 (2014) 340.

[20] H.T. Kim, J.H. Chung, D. Wang, J. Lee, H.C. Woo, I.G. Choi, K.H. Kim, Appl. Microbiol. Biotechnol. 93 (2012) 2233-2239.

[21] D. Park, S. Jagtap, S.K. Nair, J. Biol. Chem. 289 (2014) 8645-8655.

[22] M. Wang da, H.T. Kim, E.J. Yun, H. Kim do, Y.C. Park, H.C. Woo, K.H. Kim, Bioprocess Biosyst. Eng. 37 (2014) 2105-2111. 
[23] N.A. Ekborg, J.M. Gonzalez, M.B. Howard, L.E. Taylor, S.W. Hutcheson, R.M. Weiner, Int. J. Syst. Evol. Microbiol. 55 (2005) 1545-1549.

[24] S.S. Jagtap, J.H. Hehemann, M.F. Polz, J.K. Lee, H. Zhao, Appl. Environ. Microbiol. 80 (2014) 4207-4214.

[25] F. Thomas, L.C. Lundqvist, M. Jam, A. Jeudy, T. Barbeyron, C. Sandstrom, G. Michel, M. Czjzek, J. Biol. Chem. 288 (2013) 23021-23037.

[26] A. Ochiai, M. Yamasaki, B. Mikami, W. Hashimoto, K. Murata, J. Biol. Chem. 285 (2010) 24519-24528.

[27] S.W. Hutcheson, H. Zhang, M. Suvorov, Mar Drugs 9 (2011) 645-665.

[28] T. Takagi, T. Yokoi, T. Shibata, H. Morisaka, K. Kuroda, M. Ueda, Appl. Microbiol. Biotechnol. (2015).

[29] A. Ochiai, S. Mori, S. Kawai, K. Murata, Protein Expr. Purif. 36 (2004) 124-130.

[30] A. Yoshioka, K. Murata, S. Kawai, J. Biosci. Bioeng. 118 (2014) 502-507.

[31] A. Weissbach, J. Hurwitz, J. Biol. Chem. 234 (1959) 705-709.

[32] G. Andrykovitch, I. Marx, Appl. Environ. Microbiol. 54 (1988) 1061-1062.

[33] K. Nakai, M. Kanehisa, Proteins 11 (1991) 95-110. 


\section{Figure legends}

Fig. 1 Alginate metabolism. Details are described in the text.

Fig. 2 Purification of three exo-type alginate lyases. Lanes: 1, Alg17c (7.0 $\mu \mathrm{g}) ; 2$, Atu3025 $(14 \mu \mathrm{g}) ; 3$, A1-IV $(14 \mu \mathrm{g})$.

Fig. 3 Effect of dialysis and freezing on the activity of purified exo-type alginate lyases.

(A) Effect of dialysis on enzymatic activity. Purified enzymes were dialyzed at $4^{\circ} \mathrm{C}$ overnight against $20 \mathrm{mM}$ Tris- $\mathrm{HCl}(\mathrm{pH} 7.5)$ with the indicated concentrations of $\mathrm{NaCl}$ (0-300 mM). The activities of Alg17c (white), Atu3025 (light gray), and A1-IV (dark gray) were assayed and compared with those of enzymes without dialysis (w/o). (B, C) Effect of storage at $4^{\circ} \mathrm{C}$ on enzymatic activity of the enzymes with (w., open symbols) or without (w/o, closed symbols) dialysis. A1-IV (triangle), Atu3025 (circles), and Alg17c (squares) were stored at $4{ }^{\circ} \mathrm{C}$ for the indicated periods (days). Activity is presented in U/mg (B) and \% (C). (D) Effect of dialysis and freezing on enzymatic activity. Activities of Alg17c (white), Atu3025 (light gray), and A1-IV (dark gray) were dialyzed $(+)$ or not dialyzed (-), and their activities were assayed. Each enzyme with or without dialysis was frozen at $-30^{\circ} \mathrm{C}$ longer than overnight, thawed, and the activity of each enzyme was assayed (black). In some cases, activity was lost and not detected (nd). Dialyzed A1-IV was not frozen (ND) due to its sensitivity to dialysis. (A-D) Average, maximum, and minimum values are shown from two independent experiments. 
Fig. 4 Properties of three exo-type alginate lyases [Atu3025, open circles or light gray bars; Alg17c, open squares or white bars; A1-IV, closed triangles or dark gray bars]. (A) Effect of incubation period on DEH productivity from alginate. Each purified enzymes $(1 \mu \mathrm{g})$ was incubated at $30^{\circ} \mathrm{C}$ for the indicated period in the reaction mixture containing $1.0 \mathrm{mg} / \mathrm{ml}$ sodium alginate and $50 \mathrm{mM}$ Tris- $\mathrm{HCl}(\mathrm{pH} \mathrm{7.5).} \mathrm{(B)} \mathrm{Effect} \mathrm{of} \mathrm{alginate}$ concentration on DEH productivity from alginate. Each purified enzyme $(1 \mu \mathrm{g})$ was incubated as in $\mathrm{A}$ in the presence of the indicated concentrations of alginate, but for $6 \mathrm{~h}$. (C, D) Effect of $\mathrm{NaCl}$ concentration on the activity of each enzyme. Activity of each purified enzyme was assayed in the presence of the indicated concentrations of $\mathrm{NaCl}$. Activity is presented as $\mathrm{U} / \mathrm{mg}$ in $\mathrm{C}$ and as \% in $\mathrm{D}$. (A-D) Average $\pm \mathrm{SD}$ of three independent experiments. 


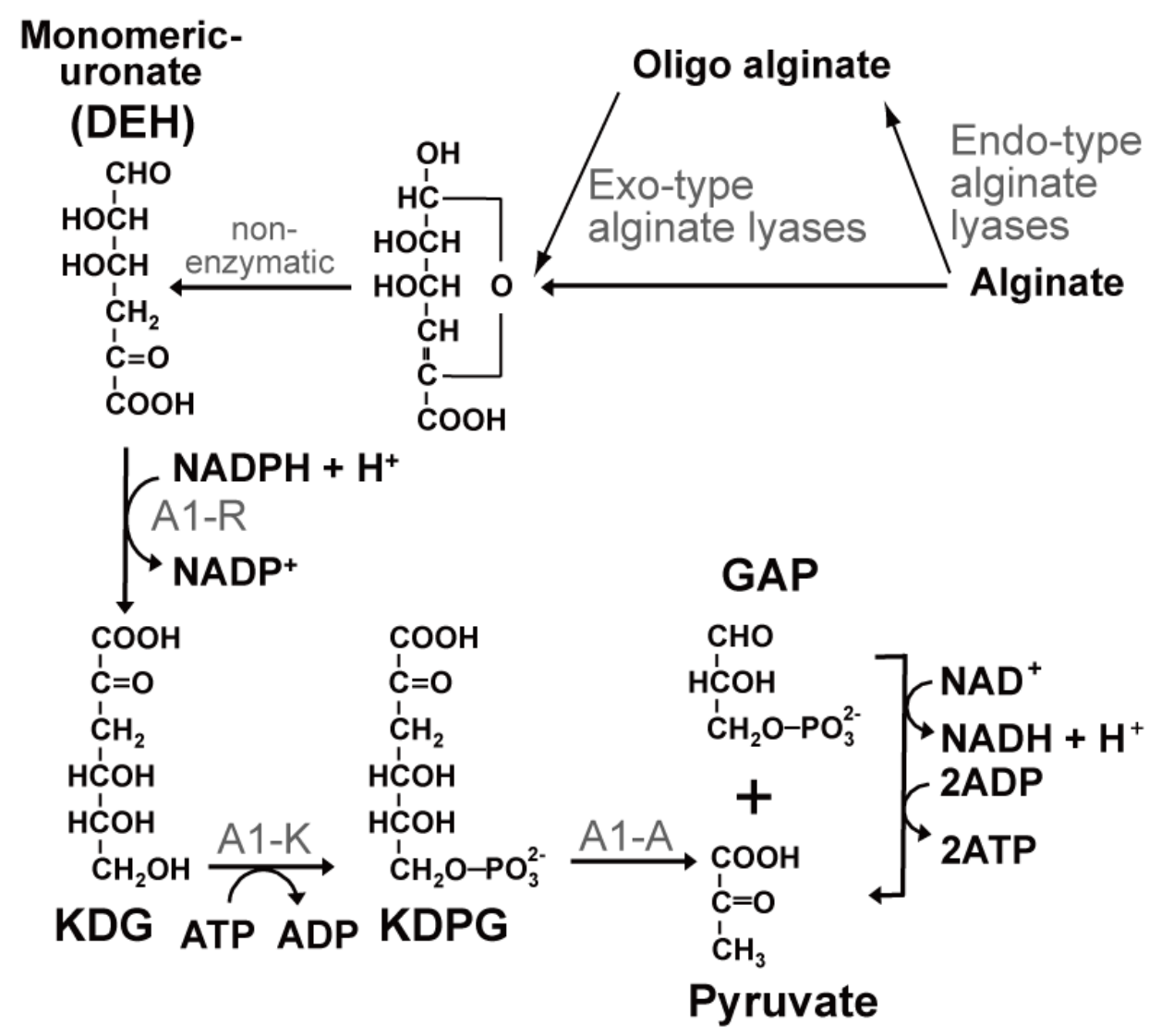

Fig. 1 


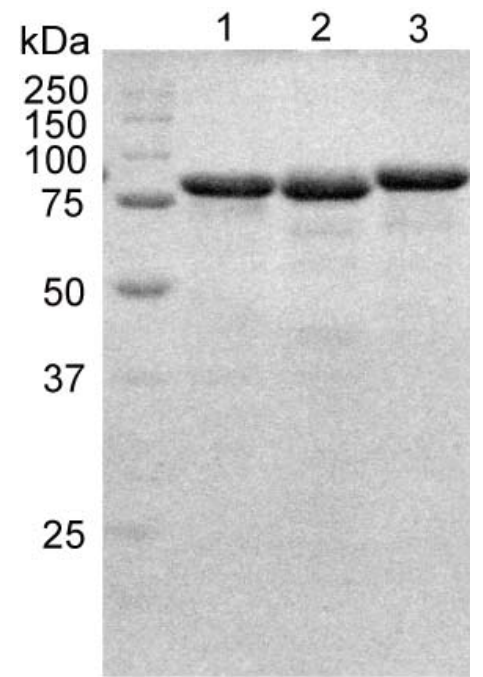

Fig. 2 

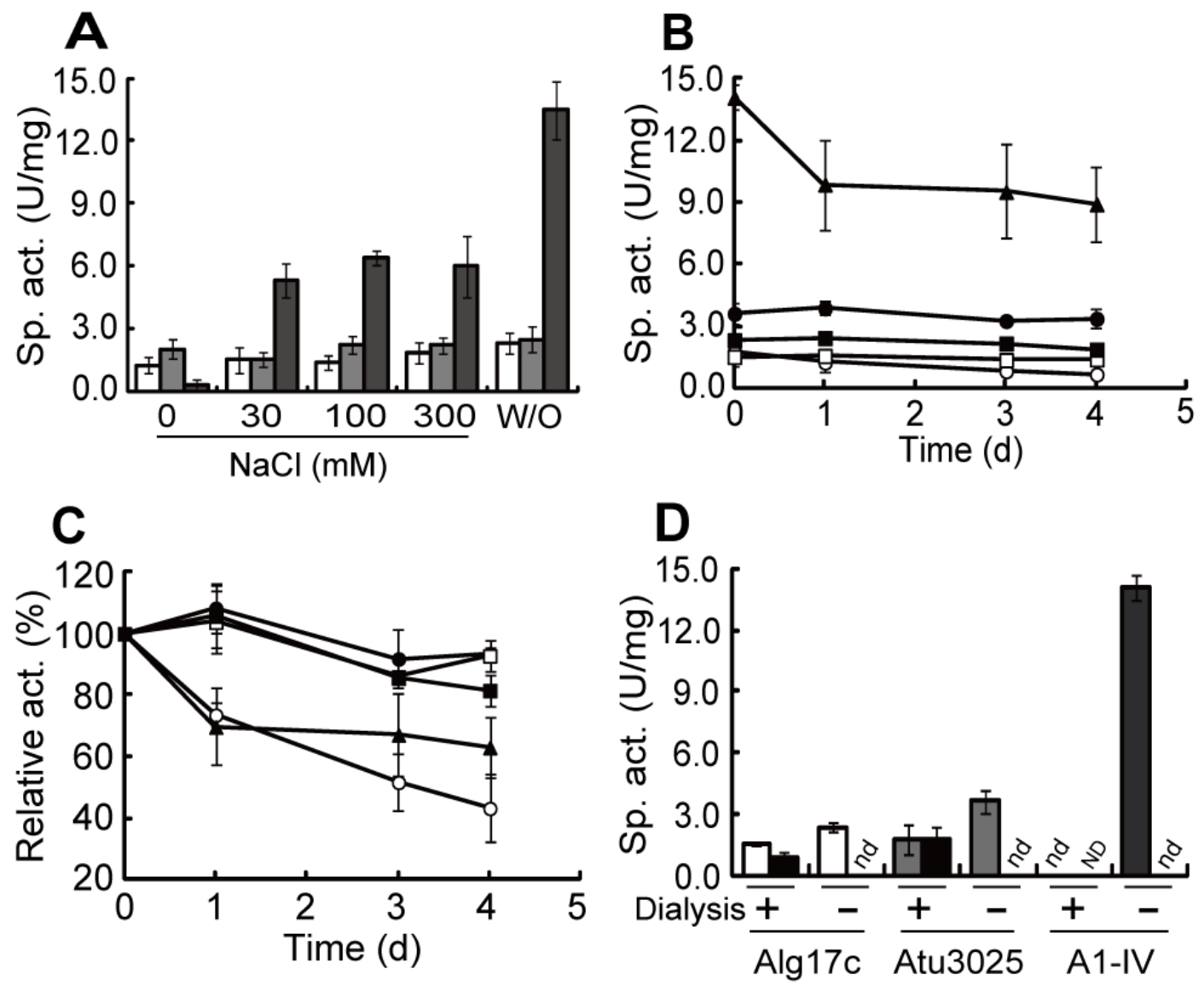

Fig. 3 

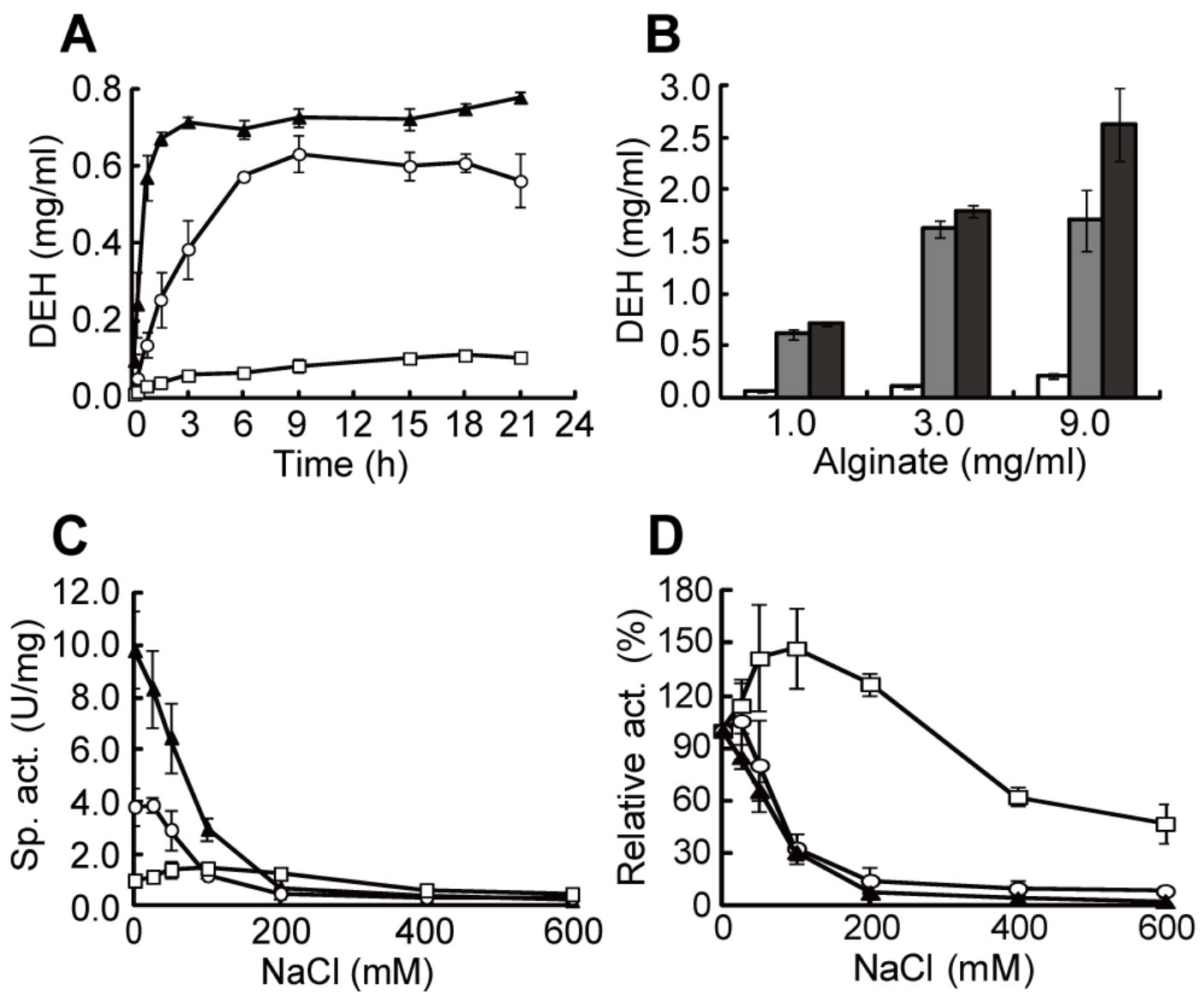

Fig. 4 
Table 1 Comparisons of assay conditions and properties of three exo-type alginate lyases from bacteria

\begin{tabular}{|c|c|c|c|}
\hline & Alg17c [19] & Atu3025 [17] & A1-IV [16] \\
\hline Reaction mixture for assay & $\begin{array}{l}20 \mathrm{mg} / \mathrm{ml} \text { sodium alginate, } 20 \\
\mathrm{mM} \mathrm{Tris-HCl} \mathrm{(pH} \mathrm{6.0),} \mathrm{total} \\
100 \mu \mathrm{l}\end{array}$ & $\begin{array}{l}0.5 \mathrm{mg} / \mathrm{ml} \text { sodium alginate, } 50 \\
\mathrm{mM} \mathrm{Tris-} \mathrm{HCl}(\mathrm{pH} 7.5) \text {, total } \\
1.0 \mathrm{ml}\end{array}$ & $\begin{array}{l}0.42 \quad \mathrm{mg} / \mathrm{ml} \text { alginate } \\
\text { trisaccharide, } 50 \mathrm{mM} \text { Tris-HCl } \\
(\mathrm{pH} 7.5) \text {, total } 10 \mu \mathrm{l}\end{array}$ \\
\hline $\begin{array}{l}\text { Amount of purified protein in } \\
\text { the reaction mixture }\end{array}$ & $50.6 \mathrm{nmol}(4,082 \mu \mathrm{g})$ in $100 \mu \mathrm{l}$ & $\mathrm{NR}^{\mathrm{a}}$ & $2.0 \mu \mathrm{g}$ in $10 \mu \mathrm{l}$ \\
\hline Reaction temperature and time & $40^{\circ} \mathrm{C}, 30 \mathrm{~min}$ & $30^{\circ} \mathrm{C}, 5 \mathrm{~min}$ & $30^{\circ} \mathrm{C}, 10 \mathrm{~min}$ \\
\hline Definition of one unit & $\begin{array}{l}\text { The amount of enzyme required } \\
\text { to release } 1.0 \mu \text { mol of the } \\
\text { reducing sugar (based on } \\
\text { glucose) }\end{array}$ & $\begin{array}{l}\text { The amount of enzyme required } \\
\text { to release } 1.0 \mu \mathrm{mol} \text { of } \\
\beta \text {-formylpyruvic acid per min }\end{array}$ & $\begin{array}{l}\text { The amount of enzyme required } \\
\text { to degrade } 1.0 \mu \mathrm{mol} \text { of } \\
\text { trisaccharide per min }\end{array}$ \\
\hline Analytical method & DNS method & TBA method & TLC analysis \\
\hline Protein assay & NR & $\begin{array}{l}\text { Based on molecular coefficient } \\
\text { at } A 280\end{array}$ & $\begin{array}{l}\text { Based on } A_{280} \text {, assuming } A_{280}= \\
1 \text { corresponds to } 1.0 \mathrm{mg} / \mathrm{ml}\end{array}$ \\
\hline Source of sodium alginate & Sigma-Aldrich & Nacalai Tesque & Nacalai Tesque \\
\hline Tertiary structure & Available & Available & Unavailable \\
\hline$K_{\mathrm{m}}(\mathrm{mM})$ & $35.2 \mathrm{mg} / \mathrm{ml}$ & $0.24 \mathrm{mg} / \mathrm{ml}$ & NR \\
\hline$V_{\max }(\mathrm{U} / \mathrm{mg})$ & $41.7 \mathrm{U} / \mathrm{mg}$ & $20.5 \mathrm{U} / \mathrm{mg}$ & NR \\
\hline Optimum temperature & $40^{\circ} \mathrm{C}$ & $30^{\circ} \mathrm{C}$ & $37^{\circ} \mathrm{C}$ \\
\hline Optimum $\mathrm{pH}$ & $\mathrm{pH} 6.0(50 \% \text { at } \mathrm{pH} 7.5)^{\mathrm{b}}$ & $\mathrm{pH} 7.3$ & $\mathrm{pH} 7.5-8.5$ \\
\hline
\end{tabular}


Table 2 Primers used in this study

\begin{tabular}{llll}
\hline No. & Primer & Sequence & Description \\
\hline 1 & Atu3025_1_20_pET & AAGGAGATATACATATGAG & For amplification of \\
& 21b_14b_Fw & ACCATCTGCTCCAGC & Atu3025 \\
& Atu3025_2310_2328 & TGCTCGAGTGCGGCCGCGA & For amplification of \\
& _ET21b_17b_Rv & ATTGCTTTGGCAAGGAC & Atu3025 \\
& dAlg17c_1_20_pET & AAGGAGATATACATATGCA & For amplification of \\
& 21b_14b_Fw & AGTTTCTGGTAACGG & Alg17c \\
4 & dAlg17c_2123_2142 & TGCTCGAGTGCGGCCGCCT & For amplification of \\
& ET21b_17b_Rv & TTCTTCTAACAACAACAG & Alg17c \\
5 & A1-IV_1_20_ET21b & AAGGAGATATACATATGAA & For amplification of \\
& 14b_Fw & GAAGCTGGAACAGCC & A1-IV \\
6 & A1-IV_2265_2283_ & TGCTCGAGTGCGGCCGCGA & For amplification of \\
& ET21b_17b_Rv & ACGGTTTGGGCAACGTG & A1-IV \\
\hline a The sequence (15 b) required for In-Fusion is in bold. NdeI and NotI sites are \\
underlined (NotI site is also in italics). Genes amplified with these primers were inserted \\
into pET-21b.
\end{tabular}


Table 3 Plasmids used in this study

\begin{tabular}{lll}
\hline Plasmids & Descriptions & Sources \\
\hline pET-21b & Ap $^{\mathrm{R}}$, E. coli expression plasmid & Novagen \\
pMK4544 & Synthesized Atu3025 gene in SacII site of pRS426 ${ }^{\mathrm{a}}$ & This study \\
pMK5306 & Synthesized Alg17c gene in pEX-K4 ${ }^{\text {a }}$ & Operon \\
pMK5398 & A1-IV gene in pET-21b & This study \\
pMK5399 & Alg17c gene in pET-21b & This study \\
pMK5400 & Atu3025 gene in pET-21b & This study \\
\hline
\end{tabular}

${ }^{\mathrm{a}}$ Genes for Atu3025 and Alg17c were synthesized at Operon. 